\title{
SPACE MINING GOVERNANCE FROM THE PERSPECTIVE OF INTERNATIONAL CONSULTATIONS WITH REGARD TO MARINE GENETIC RESOURCES AND THE MULTILATERALISM-UNILATERALISM DICHOTOMY - PRELIMINARY CONSIDERATIONS
}

\section{Eukasz Kułaga*}

Keywords: Space Mining, Marine Genetic Resources, Multilateral Obligations, Unilateralism, Governance

Abstract: The $50^{\text {th }}$ anniversary of the constitution of international space law - 1967 Treaty on Principles Governing the Activities of States in the Exploration and Use of Outer Space, including the Moon and Other Celestial Bodies (hereinafter Outer Space Treaty) coincided with enacting legislation regarding the commercial use of the space resources by the United States in November 2015 and preparation of an analogical act on the other side of the Atlantic, in Luxemburg. These domestic initiatives commenced an intensive discussion with regard to its legality, legitimacy and suitability. Until now the debate related to exploitation of the space natural resources was to large extend concentrated on the interpretation of fundamental customary and Outer Space treaty principles and did not take into account new scientific tools, which can significantly contribute to the assessment of the space mining governance. As first such

* Assistant professor, Faculty of Law and Administration, Cardinal Stefan Wyszyński University in Warsaw. 
a instrument - this article recognizes current international consultations on the marine genetic resources aimed at creation of new international regime, which can have several important similarities with the space law resources regime. As the second instrument - this article identifies multilateralism-unilateralism dichotomy, which have practical implications for process of finding international framework relating to space mining.

The issue of space mining is the subject of discussion on international fora. In particular from March 2017 it started to be discussed by the COPUOS Legal Subcommittee. The outer space technologies constitute a sector of global economy, which is considered as the most prospective one. According to European Commission "The space sector is both a driver to scientific progress and enables systems and services with growth potential (...) These systems and services (...) help us to address major societal challenges such as climate change, scarce resources. health, or the ageing of our population. (...) They stimulate innovation and competitiveness well beyond the space sector, and contribute to economic growth and job creation in almost all economic areas". This assessment is supported by figures. According to European Space Agency: "In 2015, the global space economy maintained its long-term growth trend, expanding from 14\% compared to 2014 and totaling 291.4 billion of euro. Thus, proposing new scientific instruments for international community aiming at evaluation of the space mining will constitute a valuable tool in the search for appropriate model of governance in this regard.

\section{Introduction}

The $50^{\text {th }}$ anniversary of the Constitution of International Space Law - the 1967 Treaty on Principles Governing the Activities of States in the Exploration and Use of Outer Space, including the Moon and Other Celestial Bodies (hereinafter Outer Space Treaty) - coincided with the enactment of legislation regarding the commercial use of space resources by the United States in November $2015^{1}$ and a similar act on

1 US Commercial Space Launch Competitiveness Act, Public Law No. 114-90 (11.25.2015), see also commentary to this legislation by S. Freeland, Common heritage, not common law: How international law will regulate proposals to exploit space resources, 'Questions of International Law' 2017, p. 19-33. 
the other side of the Atlantic by Luxemburg in June 2017. ${ }^{2}$ These domestic initiatives commenced an intensive discussion with regard to its legality, legitimacy and suitability.

In this context, generally recognized space law principles such as freedom of use, non-appropriation and use for benefits and interests of all countries are harshly debated by states whose opinions do not always suit the traditional divide of developing and developed countries. Whereas, the former group make a strong argument based on benefits for everyone, the latter is divided on this issue. While Luxemburg drafted legislation allowing private companies to exploit natural resources the outer space, ${ }^{3}$ its Benelux neighbours as parties to the 1979 Agreement Governing the Activities of States on the Moon and Other Celestial Bodies (hereinafter Moon Agreement) present the opinion that those resources constitute the common heritage of mankind. ${ }^{4}$ Until now the debate related to the exploitation of space natural resources was, to a large extent, concentrated on the interpretation of fundamental customary and Outer Space treaty principles ${ }^{5}$ and did not take into account new scientific instruments which can significantly contribute to the assessment of space

2 Law on the Exploration and Use of Space Resources of 20.7.2017 (Loi du 20.7.2017 sur l'exploration et l'utilisation des ressources de l'espace) entered into force on 2.8.2017, available at http://legilux.public.lu/eli/etat/leg/loi/2017/07/20/a674/jo. In accordance with 1 of this regulation: "Les ressources de l'espace sont susceptibles d'appropriation".

3 "Luxembourg is the first adopter in Europe of a legal and regulatory framework recognizing that space resources are capable of being owned by private companies," Étienne Schneider, deputy prime minister and minister of the economy", see http:// spacenews.com/luxembourg-adopts-space-resources-law/ .

4 According to Article 11 of the Moon Agreement "The moon and its natural resources are the common heritage of mankind.... (...) Neither the surface nor the subsurface of the moon, nor any part thereof or natural resources in place, shall become property of any State, international intergovernmental or non-governmental organization, national organization or non-governmental entity or of any natural person" (paras. 1 and 3$)$.

5 See for example: Does International Space Law Either Permit Or Prohibit The Taking Of Resources In Outer Space And On Celestial Bodies, And How Is This Relevant For National Actors? What Is The Context, And What Are The Contours And Limits Of This Permission Or Prohibition?, International Institute of Space Law, Directorate of Studies, 2016, http://iislweb.org/docs/IISL_Space_Mining_Study.pdf; S. Hobe, B. Schmidt-Tedd and K.U. Schrogl (ed.), Cologne Commentary on Space Law, Volume I, Carl Heymanns, 2009; S. Hobe, B. Schmidt-Tedd, K.-U. Schrogl (ed.), Cologne Commentary on Space Law, Volume II, Carl Heymanns, 2013; F. Tronchetti, The Exploitation of Natural Resources of the Moon and Other Celestial Bodies, Nijhoff, 2009. 
mining governance. Our first tool is considering current international consultations on marine genetic resources (MGR) aimed at the creation of new international regime, which can have several important similarities with the space law resources regime. The second tool - this article identifies the multilateralism-unilateralism dichotomy, which can have practical implications in the search for an international framework relating to space mining. Therefore, the purpose of this article will be preliminary evaluation of the potential of these new scientific methods for an in-depth analysis of the issue.

The use of the term 'governance' with reference to space mining aims at avoidance of concentrating only on a strict legal-illegal paradigm which does not seem to provide any long-term solution of the issue. Conversely, a governance approach allows for a broader view, which takes into account organizations, institutions, instruments and mechanisms, which can be difficult to reconcile with the traditional list of international sources of law enshrined in Article 38 of the Statute of International Court of Justice. ${ }^{6}$ Such an approach would be consistent with a method of development which dominated in international space law during the last 40 years, that is by creating principles, codes and guidelines generally labelled as soft law. ${ }^{7}$ This model intends not only to look at the process of space mining governance from a perspective which would cover not only formal international consultations and negations (its objectives and competing values), but also the unilateral actions of states, the use of countermeasures and the possibility of bringing a claim to international courts as possible remedies. ${ }^{8}$

The article pertains to issues of practical and theoretical importance. As to the first point, the issue of space mining in view of the unilateral actions of some states is the subject of discussion on international fora, in particular from March 2017 it started to be discussed by the Committee on the Peaceful Uses of Outer Space (COPUOSO Legal Subcommittee. In

6 See for example: S. Marchisio, Space Law and Governance, 10th United Nations Workshop on Space Law, 'Contribution of Space Law and Policy to Space Governance and Space Security in the 21th Century', 5-8.9.2016 Vienna, p. 1-15.

7 One of the most prominent current examples in this regard are draft guidelines for the long-term sustainability of outer space activities that are under consideration under the auspices of the Scientific and Technical Subcommittee of the Committee on the Peaceful Uses of Outer Space, see document A/AC.105/L.308, 15.2.2017.

8 M. Aliberti, S. D. Krasner, Governance in Space, [in:] C. Al-Ekabi (ed.), 'Yearbook on space policy 2014: the governance of space', Springer 2016, p. 143-166. 
June 2017 the COPUOS made a decision that discussion on this issue should be continued due to the interest of states. ${ }^{9}$ Outer space technologies constitute a sector of the global economy which, belonging to so-called sectors of new technologies, is considered as one of the most prospective. According to the European Commission:

"The space sector is both a driver to scientific progress and enables systems and services with growth potential (...) These systems and services (...) help us to address major societal challenges such as climate change, scarce resources. health, or the ageing of our population. (...) They stimulate innovation and competitiveness well beyond the space sector, and contribute to economic growth and job creation in almost all economic areas". ${ }^{10}$

This assessment is supported by figures. According to the European Space Agency: "In 2015, the global space economy maintained its longterm growth trend, expanding from 14\% compared to 2014 totalling 291.4 billion of euro". ${ }^{11}$ Thus, proposing new instruments for the international community aiming at the evaluation of space mining will constitute a valuable tool in the search for an appropriate model of governance in this regard.

The theoretical part of the article concentrates on three areas, which are of a pioneering nature. Firstly, the possibility of using ongoing discussions on the MGR as a method of searching for the best possible tools for space mining governance. Secondly, the suitability and limits of unilateralism in relation to the governance of common areas, such as outer space. Thirdly, the possibility of applying the doctrine of erga omnes obligation to areas of common interests such as outer space and its consequences, in particular with regard to engaging the international courts and third party countermeasures.

9 Report of the Committee on the Peaceful Uses of Outer Space 2017, A/72/20, $\S 244$.

10 Communication from the Commission to the European Parliament, the Council, the European Economic and Social Committee and the Committee of the Regions, EU Space Industrial Policy - Releasing The Potential For Economic Growth in the Space Sector, Brussels, 28.2.2013, COM(2013) 108 final, p. 3.

11 Final Report on the Space Economy 2016, Executive Summary, September 2016, p. 2. 


\section{Exploitation of space natural resources - international law state of play}

The assessment of the current international legal framework with regard to space mining is not an easy task. The 2016 seminal work of the International Institute of Space Law delivers the following opinion in this regard:

"space resource mining is not prohibited per se and that it is an activity falling under the freedom of the use of outer space as laid down in Article I para. 2 Outer Space Treaty, limited however by the fact that according to Article I para. 1 such use must be for the benefit of all mankind and according to Articles IV and IX must be in conformity with the provisions concerning military uses and environmental considerations (...) such use and the "free access to all areas of celestial bodies" are to be exercised under the conditions imposed by the Treaty. Apart from being one of the international legal instruments with a considerable support, the milestone norms in the Outer Space Treaty are widely accepted and may arguably even be customary law. Such are "the benefit and in the interests of all countries" clause of Article I para. 1, the prohibition of discrimination in Article I para. 2, the requirement in Article III that space activities shall be carried out "in accordance with international law", the principles of due regard and of "cooperation and mutual assistance" contained in Article IX. Thereby, the Outer Space Treaty provides a guarantee that States, in perceiving their freedom to use outer space, should ensure that these standards are met before resource mining activities can be exercised." ${ }^{12}$

A similar opinion was presented by Tanja Masson-Zwaan and Neta Palkovitz who stated that:

"As state parties to the OST are under the obligation to authorize and supervise such space activities pursuant to Article VI, waiting until states reach an international agreement relating to space resource mining would mean giving a hand to an unregulated space industry". ${ }^{13}$

12 Does International Space Law Either Permit Or Prohibit The Taking Of Resources In Outer Space And On Celestial Bodies, And How Is This Relevant For National Actors? ..., op. cit., p. 41-42

13 T. Masson-Zwaan, N. Palkovitz, Regulation of space resource rights: Meeting the needs of States and private parties, 'Questions of International Law' 2017, Zoom-in, no. 35, 
Likewise many states highlight a lack of clarity with regard to the exploitation of space resources in the Outer Space Treaty and indicate that there is a need for some internationally agreed guidelines and institutional control mechanism in this regard. ${ }^{14}$ In this context questions raised by Belgium in 2017 seem to be of paramount importance:

"How could any right of use of celestial bodies' mineral resources be granted to a national entity without allowing that entity to claim exclusive access to a dedicated area of the celestial body surface and underground? How can the limitations in terms of size and duration of activities associated with such right of use be determined in a manner that would respect the freedoms of others as stipulated in the fundamental provisions of the Outer Space Treaty?"15

This issue was also mentioned by China, which indicated that an exclusive approach with regard to the exploitation of resources could violate the Outer Space Treaty and that there is a need to ensure that all state benefit from the use of outer space. ${ }^{16}$

\section{Space Mining Governance from the Perspective of International Consultations with regard to Marine Genetic Resources}

In resolution 69/292 of 19.6.2015, the United Nations General Assembly (hereinafter the UN GA) decided to develop an international

p. 17; see also R. J. Lee, Law and regulation of commercial mining of minerals in outer space, Springer 2012, p. 315-322.

14 See position of GRULAC, France, 'G77 and China' presented at COPUOS Legal Subcommittee during its fifty-sixth session in 2017 on agenda item 13 "General exchange of views on potential legal models for activities in exploration, exploitation and utilization of space resources" on 28.4.2017, see http://www.unoosa.org/oosa/audio/v2/meetings. jsp?lng=en

15 Contribution from Belgium to the discussion under UNCOPUOS Legal Subcommittee on item "General exchange of views on potential legal models for activities in exploration, exploitation and utilization of space resources", 28.3.2017, A/ AC.105/C.2/2017/CRP.19, p. 2-3.

16 Position of China presented at COPUOS Legal Subcommittee during its fifty-sixth session in 2017 on agenda item 13 "General exchange of views on potential legal models for activities in exploration, exploitation and utilization of space resources" on 28.4.2017, see http://www.unoosa.org/oosa/audio/v2/meetings.jsp?lng=en 
legally binding instrument under the United Nations Convention on the Law of the Sea (hereinafter the UNCLOS) on the conservation and sustainable use of marine biological diversity of areas beyond national jurisdiction. One of the most important and controversial elements of the agreed package of topics concerns "marine genetic resources, including questions on the sharing of benefits". ${ }^{17}$ Marine genetic resources are defined as "any marine genetic material of plant, animal, or microbial origin of actual or potential value collected from the Area". ${ }^{18}$ Before holding an intergovernmental conference, the UN GA decided to establish a Preparatory Committee, which started its work in 2016, to make substantive recommendations for the elements of a draft text of an international legally binding instrument under UNCLOS. ${ }^{19}$ These international consultations can have legal significance, by using an analogy or systemic interpretation, for space mining governance.

Although the analogy is not a particularly satisfactory method when dealing with the exceptional legal status of outer space, undeniably it has been broadly used in this regard. Such an approach can be justified from a practical perspective. In the absence of precise norms relating to outer space there is a need to build some arguments or search for common patterns by using different methods of legal reasoning including an analogy. Space regulations are often compared with the regime of the high seas and deep seabed, the Antarctic or even exclusive economic zones. A combined analysis of the phenomena of these regimes has been already undertaken

17 Outcome of the Ad Hoc Open-ended Informal Working Group to study issues relating to the conservation and sustainable use of marine biological diversity beyond areas of national jurisdiction and Co-Chairs' summary of discussions, 13.2.2015, A/69/780 , para. 1; see also K. J. Marciniak, Marine Genetic Resources: Do They Form Part of the Common Heritage of Mankind Principle?, [in:] L. Martin, C. Salonidis, C. Hioureas (ed.), 'Natural Resources and the Law of the Sea: Exploration, Allocation, Exploitation of Natural Resources in Areas under National Jurisdiction and Beyond', Juris 2017; D. Tladi, The Common Heritage of Mankind and the Proposed Treaty on Biodiversity in Areas beyond National Jurisdiction: The Choice between Pragmatism and Sustainability, 'Yearbook of International Environmental Law' 2014, vol. 25, p. 113-132.

18 Chair's non-paper on elements of a draft text of an international legallybinding instrument under the United Nations Convention on the Law of the Sea on the conservation and sustainable use of marine biological diversity of areas beyond national jurisdiction, 28.2.2017, p. 6.

19 T. Scovazzi, The negotiations for a binding instrument on the conservation and sustainable use of marine biological diversity beyond national jurisdiction, 'Marine Policy' 2016, vol. 70, p. 188-191. 
from different perspectives under the theories of shared responsibilities, ${ }^{20}$ global commons ${ }^{21}$ and global public goods. ${ }^{22}$ Nonetheless, the regime of outer space was not given a great deal of time in those studies.

From a normative perspective, the principle of systemic integration enshrined in Article 31 paragraph 3 letter $\mathrm{c}$ of the Vienna Convention on the Law of Treaties, as pointed out by the International Law Commission "refers back to the wider legal environment, indeed the "system" of international law as a whole". ${ }^{23}$

Thus, the analysis of ongoing discussions on MGR as a method of searching for the best possible tools for space mining governance seems to be natural when taking into account the similarities of the two regimes. Firstly, they both relate to areas which cannot be appropriated by states. Secondly, they both concern the possibilities of extraction of resources from this area. Thirdly, in both situations the quest for equitable sharing has an important role to play. Fourthly, both issues touch important formal question, which is a relation of a possible new legal instrument to an applicable treaty of a constitutional character that is the United Nations Convention on the Law of the Sea with regard to MGR and the Outer Space Treaty with regard to space mining. In this context one can only agree that any new document that would be crafted should preserve a delicate balance of rights, obligations and interests achieved in an applicable framework convention. ${ }^{24}$

20 A. Nollkaemper, D. Jacobs, Shared Responsibility in International Law: A Conceptual Framework, 'Michigan Journal of International Law' 2013, vol. 3, no. 2, p. 359-438.

21 Susan J. Buck, The Global Commons: An Introduction, Island Press, Washington 1998; According to UNEP “The 'Global Commons' refers to resource domains or areas that lie outside of the political reach of any one nation State. Thus international law identifies four global commons namely: the High Seas; the Atmosphere; Antarctica; and, Outer Space", see http://staging.unep.org/delc/GlobalCommons/tabid/54404/Default.aspx .

22 D. Bodansky, What's in a Concept? Global Public Goods, International Law, and Legitimacy, 'EJIL' 2012, vol. 23 no. 3, p. 651-668.

${ }^{23}$ 'Fragmentation of international law: difficulties arising from the diversification and expansion of international law', Report of the Study Group of the International Law Commission Finalized by Martti Koskenniemi, 13.4.2006, A/CN.4/L.682, par. 479.

${ }^{24}$ Chair's overview of the first session of the Preparatory Committee established by General Assembly resolution 69/292: Development of an international legally binding instrument under the United Nations Convention on the Law of the Sea on the conservation and sustainable use of marine biological diversity of areas beyond national jurisdiction, p. 4. 
The international consultations on MGR also indicate the necessity to take into account other related documents and treaties. With respect to the governance of space mining one has to take into account standards adopted by the UN GA, contained in particular in: the Declaration on International Cooperation in the Exploration and Use of Outer Space for the Benefit and in the interest of all States, Taking into Particular Account the Needs of Developing Countries ${ }^{25}$ and the Space Debris Mitigation Guidelines. ${ }^{26}$ Furthermore, the Guidelines for the long-term sustainability of outer space activities which are currently being considered by the COPUOS also can have significance in this respect. ${ }^{27}$

As the discussion on a new regime of MGR shows the most difficult point would be to reconcile between equity and equality ("first come, first serve") considerations. ${ }^{28}$ The former argument is based on the conviction that "conservation and sustainable use of marine biodiversity beyond areas of national jurisdiction could not be left to unilateral action or to organizations with limited participation and that common goods could not be appropriated by or left to the exclusive administration of a few which did not represent the interests of the international community" ${ }^{29}$ while the latter expressed in more diplomatic language it states that "the package was not robust enough to constitute the basis for negotiations of a new instrument". ${ }^{30}$ The quest for a sustainable equilibrium in this regard would have to answer several important questions: whether it is better to have a new regime without a globally reached acceptance instead of the current vague legal framework? Whether a balance could be calibrated while taking

25 Resolution $51 / 122$ of 13.12 .1996$.

26 Resolution 62/217 of 22.12.2007.

27 Committee on the Peaceful Uses of Outer Space, Draft report - Sixtieth session, 15.6.2017, A/AC.105/L.309/Add.1, para. 110.

28 "With regard to guiding principles, discussions focused on the legal regime applicable to marine genetic resources of areas beyond the national jurisdiction with views still divergent on the applicable legal regime, namely the common heritage of mankind or the freedom of the high seas", see: Informal working group on marine genetic resources, including questions on the sharing of benefits, Oral report of the Facilitator to the plenary, 4.4.2017, http://www.un.org/Depts/los/biodiversity/prepcom_files/ Chair_Overview.pdf

29 Outcome of the Ad Hoc Open-ended Informal Working Group to study issues relating to the conservation and sustainable use of marine biological diversity beyond areas of national jurisdiction and Co-Chairs' summary of discussions, 13.2.2015, A/69/780, para. 12 .

$30 \quad$ Ibidem., para. 28. 
into account not only concerns of developing countries but also be open for the interest of states which have de facto capabilities to use these specific resources? With regard to the latter, Fabio Tronchetti accurately points out that:

"it is an unquestionable fact that without the involvement of spacefaring nations and private operators, who are the only subjects having the financial and technological capabilities to exploit the natural resources of the Moon and other celestial bodies, this exploitation will never take place. Therefore, the legal regime has to be structured in such a way as to appear attractive to these subjects and to provide them with the concrete possibility to make a profit from the exploitation of space resources". ${ }^{31}$

Thus, the issue of benefit sharing/burden sharing makes creating a regime of exploitation of common economic resources, whether it is the Area, the Antarctic (if it would be possible), the high seas (MGR) or outer space particularly problematic. This topic requires, on the one hand, the need to take into account reasonable demands from developing states but from the other, reasonable expectation of profit by states and their entities, whether public or private, which undertook significant work and invested substantial resources for having the possibility to make profit from space mining activities. In this context the article acknowledges difference between MGR, which are living resources from space minerals. ${ }^{32}$ Nonetheless, the distinctiveness of MGR potential use ("the costly research and development phase is usually needed before an actual product is put on the market") ${ }^{33}$ has full applicability also to space resources.

The perspective of specific features of space law adds two important additional elements to this process. In practice, crafting a new treaty does not always solve the problem. The lack of support of states for the Moon Treaty signifies that even establishing a new legally binding instrument can have an extremely limited role in resolving international tensions and controversies. In this context it is worth taking into account the experience

31 F. Tronchetti, The Exploitation of Natural Resources of the Moon and Other Celestial Bodies, op. cit., p. 288.

32 See Written submission of the EU and its Member States marine genetic resources, including questions on the sharing of benefits, 22.2.2017, available at:

http://www.un.org/depts/los/biodiversity/prepcom_files/rolling_comp/EU_Written_ Submission_on_Marine_Genetic_Resources.pdf, p. 3.

33 Ibidem. 
and wisdom of the development of space law in the last 40 years. Noticing a lack of consensus for new treaties and the lack of success of the Moon Treaty means this branch of international law has been steadily developed through soft law instruments. ${ }^{34}$

Transplanting the discussion of the MGR package to the governance of space mining resources allows for several proposals. At the basic level, taking into account the space law non-appropriation principle and freedom of use there is a need for strengthening cooperation and coordination mechanisms between states. Thus, there is a need for creating a platform which would not only collect information from states, as with the UN Office of Outer Space which registers space objects, but also which would request from states information if they do not deliver it without undue delay, on a voluntary basis. Such a mechanism seems to be necessary not only for enhancing information about the safety of space objects' operation and the mitigation of space debris, but also for monitoring the space environment and the outcomes of any space mining for the long-term sustainable use of outer space. This could also involve creating regular meeting of states for discussion, exchange of views and information or the creation of a standing item during COPUOS sessions.

The process and result of negotiations on MGR is a significant indicator whether the international community as a whole can find a solution with regard to the exploitation of common economic resources, in particular also space resources.

One may find much inspiration in the recommendations contained in the report of the Preparatory Committee, which can be considered useful in the process of constructing a space mining framework. These include introducing provisions on monitoring the utilization of space resources, considering principles and approaches guiding benefit-sharing, such as being beneficial to current and future generations and promoting scientific space research and research and development. ${ }^{35}$

34 M. Ferrazzani, 'Soft Law in Space Activities - An Updated View', [in:] I. Marboe (ed.), 'Soft Law in Outer Space: The Function of Non-Binding Norms in International Space Law’, Böhlau 2012, p. 99-102.

35 Report of the Preparatory Committee established by General Assembly resolution 69/292: Development of an international legally binding instrument under the United Nations Convention on the Law of the Sea on the conservation and sustainable use of marine biological diversity of areas beyond national jurisdiction, 31.7.2017, A/ C.287/2017/PC.4/2, p. 10-11. 


\section{Space Mining Governance from the Perspective of the Multilateralism-Unilateralism Dichotomy}

Regardless of the result of the negotiations on MGR, there exists another important instrument, which should be taken into account with regard to governance of space mining i.e. the multilateralism-unilateralism dichotomy. What is important, this tool allows for evaluation of state actions, which can have an indirect or direct impact on their willingness to negotiate the international framework for space mining, analogical to the one negotiated for the MGR.

The space mining governance from the perspective of the multilateralism-unilateralism dichotomy requires an analysis of at least two layers. Firstly, the legitimacy of unilateral measures aimed at the extraction of resources situated outside a state's territory and relating to common areas. Secondly, the existence of multilateral, non-contingent obligations in space law and its potential of engaging international courts or using third party countermeasures as tools for space mining governance.

\section{Unilateralism and space mining governance}

Unilateralism can be considered as a form of realization of the international relations of states which do not recognize international cooperation, particularly on a global or multilateral scale as an important mechanism. Thus, unilateral actions constitute typically individual initiatives of one state or a narrow group of states. ${ }^{36}$ Controversies with regard to unilateralism from the perspective of international law concern, in particular, its applicability to common areas such as outer space, which are considered as engaging the interest of the international community as a whole. ${ }^{37}$ In this context, several important questions arise i.e. to what extent can states unilaterally delimit their jurisdiction in such territories, specifically with regard to the issue of mineral extraction and how such a process influences the rights of others and the common nature of the area? Or whether the standard of Principle 12 of the Rio Declaration referring

36 P.-M. Dupuy, The place and role of unilateralism in contemporary international law, 'EJIL' 2000, vol. 11, no. 1, p. 19-22.

37 See D. Alland, Countermeasures of General Interest, 'EJIL' 2002, vol. 13, p. 1221-39. 
to the need of avoidance of unilateral action would be applicable? ${ }^{38}$ Or is unilateral extraction of non-living resources in the area where states do not have sovereign rights possible under international law?

The origin of this debate can be traced to the theoretical foundations of both concepts. While at the heart of unilateralism, is an individual state's interest based on the theory of realism, creating a framework for common areas which are of interest to the international community, inspired by regime theory. ${ }^{39}$

In the sphere where there is no consensus with regard to an applicable legal regime, such as the extraction of natural resources in outer space, unilateralism seems to be, at least for some states, a plausible option. Therefore, the doctrine of unilateralism can be considered a useful tool for evaluation of US or Luxembourg activities relating to the commercial use of outer space resources. Unilateralism theory explains why states do not always consider a multilateral approach as serving their needs. It is remarkable that in relation to space mining the unilateral method is used not only by a global power (the United States), but more typically also by a small state (Luxembourg), deeply engaged in international integration and cooperation processes based on international law. Preliminary observations in this regard are based on the assumption that unilateral actions can bring positive results. ${ }^{40}$ They can either stimulate other stakeholders to more actively engage in crafting a new international regime or, when it would be impossible due a lack of consensus, they can contribute to the creation of customary international norms or constitute the subsequent practice of states influencing an interpretation of the Outer Space Treaty. ${ }^{41}$

38 "Unilateral actions to deal with environmental challenges outside the jurisdiction of the importing country should be avoided. Environmental measures addressing transboundary or global environmental problems should, as far as possible, be based on an international consensus", see The Rio Declaration on Environment and Development, 31 ILM 1992, 874; see also: P. Sands, 'Unilateralism', values, and international law, 'EJIL' 2000, vol. 11, no. 2, p. 291-302.

39 A. Nollkaemper, Unilateralism/Multilateralism, online Max Planck Encyclopedia of Public International Law, para. 6.

40 D. Bodansky, What's so bad about unilateral action to protect the environment?, 'EJIL' 2000, vol. 11, no. 2, p. 339-347; M. Hakimi, Unfriendly Unilateralism, 'Harvard International Law Journal' 2014, vol. 55, no. 1, p. 107-108 and 121-126.

41 Issue connected with the concept of unilateralism that is a right to apply countermeasures as described in the context of multilateral obligations; see also J. Myers, Extraterrestrial Property Rights: Utilizing the Resources of the Final Frontier, 'San Diego International Law Journal' 2016, vol. 18, p. 107-112, 123-127. 


\section{Multilateralism (Multilateral Obligations) and Space Mining Governance}

One of the most crucial elements of the concept of multilateralism in international law relates to the doctrine of communitarian norms, in particular non-contingent obligations. ${ }^{42}$ As the concept of multilateralism has a much broader meaning, this article will concentrate only on the normative element, which can labelled as the issue of multilateral obligations. ${ }^{43}$ In this context one has to admit that a taxonomy of space law obligations is an important, though neglected, distinction. Classifying obligations as either bilateral or collective in nature has crucial legal consequences, in particular with regard to the possibility of the invocation of international responsibility. If the international community does not find consensus on the new framework of space mining governance, one can wonder whether international courts in particular the International Court of Justice (hereinafter ICJ or the Court) will be the appropriate authority for giving a substantial response to this controversy. In questions relating to the obligation to prosecute or extradite (Belgium v. Senegal) the Court taking into account the preamble and object and purpose of the Convention against torture stated that parties to the Convention have a common interest and cooperate on the bases of shared values. ${ }^{44}$ According to the ICJ:

"The common interest in compliance with the relevant obligations under the Convention (...) implies the entitlement of each State party to the Convention to make a claim concerning the cessation of an alleged breach by another State party. If a special interest were required for that purpose, in many cases no State would be in the position to make such a claim". ${ }^{4}$

Thus, the Court applied the concept of "obligations erga omnes partes", which is also relevant to some obligations enshrined in the Outer Space Treaty. Acknowledging that each State party of this treaty has an interest in ensuring compliance with it, in any given case, could open a spectrum

42 J. Crawford, Chance, Order, Change: The course of International law, 'RCADI' 2014, p. 194-204

43 J. Crawford, Multilateral Rights and Obligations in International Law, 'RCADI' 2006, p. 344.

44 Judgment of 20.7.2012, ICJ Rep. 2012, para. 68.

45 Ibidem, para. 69. 
of possibilities for raising the issue of space mining in an international legal fora. It is submitted that contemporary international space law should be considered as moving well beyond bilateralism, particularly with respect to the space environment and benefit for mankind principle. In the context of the environment, Bruno Simma inidicates that "this field provides a particularly impressive illustration of the movement from bilateralism to community concern in international law". "Similarly, when referring to the common heritage of mankind concept he states that "the traditional instinct of "first come, first served" and the acceptance of community interests remain uneasy companions". ${ }^{47}$ Both of the these elements, that is environmental considerations and benefit for mankind principle, are being raised in the debate regarding unilateral space mining initiatives.

The conviction that the concept of obligation erga omnes partes can be applied to territorial regimes of common interest and not only to human rights treaties seems to be firmly grounded in international law. In the seminal Barcelona Traction judgment, the ICJ indicated that "all States can be held to have a legal interest" in the protection of the rights of great importance. ${ }^{48}$ Article 19 of the Draft Articles on Responsibility of States for Internationally Wrongful Acts defining international crimes stated that they entail also "The breaches of international law concerning (...) the obligations to safeguard and preserve the human environment". Similarly, the Institute of International law indicated that "a wide consensus exists to the effect that (...) obligations relating to the environment of common spaces are examples of obligations reflecting those fundamental values". ${ }^{49}$ Finally, with regard to the UNCLOS it was stated that "Each State Party may also be entitled to claim compensation in light of the erga omnes character of the obligations relating to preservation of the environment of the high seas and in the Area". ${ }^{\circ}$

Nonetheless, with the exception of the cited advisory opinion of the International Tribunal for the Law of the Sea, until now the doctrine

46 B. Simma, From Bilateralism to Community Interest, 'RCADI' 1994, p. 238.

47 Ibidem, p. 242.

48 Barcelona Traction, Light and Power Company, Limited (Belgium v. Spain), Second Phase, Judgment, I.C.J. Reports 1970, p. 32, para. 33.

49 Institute of International Law, Resolution on Obligations erga omnes in International Law, IDI Resolution I/2005, 71(2) Ann IDI 286.

50 International Tribunal for the Law of the Sea, Responsibilities and obligations of States sponsoring persons and entities with respect to activities in the Area, List of cases: No. 17, Advisory Opinion of 1.2.2011, para. 180. 
of the erga omnes obligation was not applied in international law practice to areas of common interests such as outer space. This could be a consequence of a lack of fundamental disputes between states in this regard. The issue of outer space mining could be the first example, when the erga omnes nature of obligations relating to the common area can have practical implication

One can distinguish at least two possible consequences of applying the doctrine of erga omnes (or more precisely erga omnes partes) obligation to the Outer Space Treaty regime. These are a right to use countermeasures by third states and a possibility of bringing a claim to an international court. With regard to the latter, in view of the lack of a specialized international court with jurisdiction regarding outer space issues, it seem that the ICJ, as the only international court of general competence, would suit this purpose. However, one cannot forget that "the erga omnes character of a norm and a rule of consent to jurisdiction are two different things". ${ }^{51}$ Taking into account that there is no appropriate treaty clause providing for a jurisdiction of the Court, states which would be determined to initiate an inter-state proceeding could ensure access to the ICJ through a mechanism of optional declarations under Article 36 of the ICJ Statute. What is important, currently, from the 72 states which deposited declarations recognizing as compulsory the jurisdiction of the Court, 54 are Parties to the Outer Space Treaty. Nonetheless, as it was indicated by James Crawford, "The will and power to make use of the communitarian vehicle remains at the discretion of each member of the international community". ${ }^{2}$

Some example of such an approach could be seen in the Australian application instituting proceedings against Japan in Whaling in the Antarctic. In particular, Australia invoked Japan's obligations erga omnes partes under the Whaling Convention and erga omnes in the context of environmental protection under CITES and the Convention on Biological Diversity. ${ }^{53}$ However, the Court remained silent on this issue. ${ }^{54}$

51 East Timor (Portugal v. Australia), ICJ Rep. 1995, p. 102, para. 29.

52 J. Crawford, Responsibility for Breaches of Communitarian Norms: an Appraisal of Article 48 of the ILC Articles on Responsibility of States for Internationally Wrongful Acts, [in:] U. Fastenrath, R. Geiger, D.-E. Khan, A. Paulus, S. von Schorlemer, C. Vedder (eds), 'From Bilateralism to Community Interest: Essays in Honour of Bruno Simma', Oxford 2011, p. 240.

53 Whaling in the Antarctic (Australia v Japan), Application Instituting Proceedings of 31.5.2010, para. 32 .

54 Whaling in the Antarctic (Australia v. Japan: New Zealand intervening), ICJ Rep. 2014 
Other venues of judicial engagement i.e. advisory proceedings can also be evaluated in this regard. Questions regarding the territorial regimes of common interest seems to be particularly suitable for an advisory opinion of the ICJ. ${ }^{55}$ Undoubtedly, they should not be considered as to be "of such a character as should lead it to decline to answer the request" ${ }^{56}$ by the Court. Until now, although not referring directly to common areas, the ICJ has issued several advisory opinions that touched upon communitarian norms. ${ }^{57}$

The second possible consequence of applying the doctrine of erga omnes obligations is the possibility of using countermeasures against a state which eventually violates the Outer Space Treaty regime through space mining activities. This issue of so-called third state countermeasures was recognized, but not regulated by the International Law Commission in its articles on the responsibility of states. ${ }^{58}$ Current international practice suggests that there exists a solid tendency for acknowledging that international law accepts the right of third state countermeasures for at least some violations of erga omnes obligations, particularly concerning the basic rights of an individual or the prohibition of the use of force, reserving all other conditions for the legality of countermeasures are satisfied. ${ }^{59}$ Still however "States do not rush into 'third party reprisals',

55 Compare to "t]he opinion is requested on a question which is of particularly acute concern to the United Nations", Legal Consequences of the Construction of a Wall in the Occupied Palestinian Territory, ICJ. Rep. 2004, para. 50.

56 Western Sahara, ICJ Rep. 1975, para. 23.

57 Reservations to the Convention on the Prevention and Punishment of the Crime of Genocide, ICJ Rep. 1951; Legal Consequences for States of the Continued Presence of South Africa in Namibia (South West Africa) notwithstanding Security Council Resolution 276 (1970), ICJ Rep. 1971; Legality of the Threat or Use of Nuclear Weapons, ICJ Rep. 1996; Legal Consequences of the Construction of a Wall in the Occupied Palestinian Territory, ICJ Rep. 2004.

58 "This chapter does not prejudice the right of any State, entitled under Article 48, paragraph 1 , to invoke the responsibility of another State, to take lawful measures against that State to ensure cessation of the breach and reparation in the interest of the injured State or of the beneficiaries of the obligation breached" (Article 54. Measures taken by States other than an injured State), 'Yearbook of the International Law Commission', 2001, vol. II (Part Two); see also similar provision in Articles on the Responsibility of International Organizations (Article 57), 'Yearbook of the International Law Commission', 2011, vol. II (Part Two).

59 P.-M. Dupuy, Back to the Future of a Multilateral Dimension of the Law of State Responsibility for Breaches of 'Obligations Owed to the International Community as a Whole', 'EJIL' 2012, vol. 23, no. 4, p. 1068-1069; C. J. Tams, Enforcing obligations "erga omnes” in 
but employ them cautiously - probably aware that they must not be seen as a 'violent mob"'. ${ }^{\circ}$

Whether such a right is in the process of development with regard to areas of common interests needs further study as it is an issue of paramount significance for space mining governance. As Christian Tams forcefully argues in this context: "Unlike the right to institute erga omnes proceedings before the ICJ, the right to take countermeasures would not be subject to jurisdictional constraints; it could be exercised by all States, and, more importantly, against all States (and not only against States having consented to the Court's jurisdiction)". ${ }^{61}$

\section{Conclusions}

The purpose of this article was to make preliminary observations on possible new tools for space mining governance. In this regard two instruments were proposed: international consultations currently held under UN auspices on marine genetic resources and the multilateralismunilateralism dichotomy. Both of these tools are suitable in the search for a solution to the controversies that have arisen in the context of enacting space mining legislation by the United States and Luxemburg.

Simultaneously, one has to recognize that these methods can have significance on different levels. While the first method can be helpful for both the interpretation of the existing legal regime as well as creating a new one if the international community so decides, the second method

international law, Cambridge 2009, p. 230-231; M. Dawidowicz, Third-party countermeasures: A progressive development of international law?, 'Questions of International Law' 2016, vol. 4, p. 3-15; see also M. Dawidowicz, Third-Party Countermeasures in International Law, Cambridge 2017.

60 C. J. Tams, Individual States as Guardians of Community Interests, [in:] U. Fastenrath, R. Geiger, D.-E. Khan, A. Paulus, S. von Schorlemer, C. Vedder (eds), 'From Bilateralism to Community Interest: Essays, In Honour of Bruno Simma', Oxford 2011, p. 392; In this context to the point is the conclusion of this author that: "While it would be simplistic to state that States never wanted to act as guardians of community interests, it seems fair to say that they assert their considerable enforcement powers very selectively. International rules on decentralized enforcement therefore seem to be ahead of State practice; the law seems to allow more than States typically want" (p. 400).

61 C. J. Tams, Enforcing Obligations "erga omnes" in International Law, Cambridge 2009, p. 198. 
can be considered as a potentially new path of solving disputes relating to space resources, regardless of whether a new legal framework will be agreed upon or not.

\section{Bibliography}

1. Aliberti M., Krasner S. D., Governance in Space, [in:] C. Al-Ekabi (ed.), 'Yearbook on space policy 2014 : the governance of space', Springer 2016, p. 143-166

2. Alland D., Countermeasures of General Interest, 'EJIL' 2002, vol. 13

3. Bodansky D., What's in a Concept? Global Public Goods, International Law, and Legitimacy, 'EJIL' 2012, vol. 23, no. 3

4. Bodansky D., What's so bad about unilateral action to protect the environment?, 'EJIL' 2000, vol. 11 no 2

5. Buck Susan J., The Global Commons: An Introduction, Island Press, Washington 1998;

6. Crawford J., Chance, Order, Change: The course of international law, 'RCADI' 2014

7. Crawford J., Multilateral Rights and Obligations in International Law, 'RCADI' 2006

8. Crawford J., Responsibility for Breaches of Communitarian Norms: an Appraisal of Article 48 of the ILC Articles on Responsibility of States for Internationally Wrongful Acts, [in:] U. Fastenrath, R. Geiger, D.-E. Khan, A. Paulus, S. von Schorlemer, C. Vedder (eds.), 'From Bilateralism to Community Interest: Essays in Honour of Bruno Simma', Oxford 2011

9. Dawidowicz M., Third-party countermeasures: A progressive development of international law?, 'Questions of International Law' 2016 , vol. 4

10. Dawidowicz M., Third-Party Countermeasures in International Law, Cambridge 2017

11. Dupuy P.-M., The place and role of unilateralism in contemporary international law, 'EJIL' 2000, vol. 11, no. 1

12. Dupuy P.-M., Back to the Future of a Multilateral Dimension of the Law of State Responsibility for Breaches of 'Obligations Owed to the International Community as a Whole', 'EJIL' 2012, vol. 23 no. 4

13. Ferrazzani M., 'Soft Law in Space Activities - An Updated View', [in:] I. Marboe (ed.), 'Soft Law in Outer Space: The Function of Non-Binding Norms in International Space Law', Böhlau 2012

14. Freeland S., Common heritage, not common law: How international law will regulate proposals to exploit space resources, 'Questions of International Law' 2017 
15. Hakimi M., Unfriendly Unilateralism, 'Harvard International Law Journal' 2014, vol. 55, no. 1

16. Hobe S., B. Schmidt-Tedd and K.-U. Schrogl (eds.), Cologne Commentary on Space Law, vol. I, Carl Heymanns, 2009, vol. II, Carl Heymanns, 2013

17. International Institute of Space Law, Directorate of Studies, Does International Space Law Either Permit Or Prohibit The Taking Of Resources In Outer Space And On Celestial Bodies, And How Is This Relevant For National Actors? What Is The Context, And What Are The Contours And Limits Of This Permission Or Prohibition? 2016, available at http://iislweb.org/docs/IISL_ Space_Mining_Study.pdf;

18. Lee, R. J. , Law and regulation of commercial mining of minerals in outer space, Springer 2012, p. 315-322.

19. Marchisio S., Space Law and Governance, 10th United Nations Workshop on Space Law, 'Contribution of Space Law and Policy to Space Governance and Space Security in the 21th Century', 5-8.9.2016 Vienna

20. Marciniak K. J., Marine Genetic Resources: Do They Form Part of the Common Heritage of Mankind Principle?, [in:] L. Martin, C. Salonidis, C. Hioureas (eds.), 'Natural Resources and the Law of the Sea: Exploration, Allocation, Exploitation of Natural Resources in Areas under National Jurisdiction and Beyond', Juris 2017

21. Masson-Zwaan T., Palkovitz N., Regulation of space resource rights: Meeting the needs of States and private parties, 'Questions of International Law' 2017, Zoom-in, no. 35

22. Myers J., Extraterrestrial Property Rights: Utilizing the Resources of the Final Frontier, 'San Diego International Law Journal' 2016, vol. 18

23. Nollkaemper A., Unilateralism/Multilateralism, online Max Planck Encyclopedia of Public International Law

24. Nollkaemper A., Jacobs D., Shared Responsibility in International Law: A Conceptual Framework, 'Michigan Journal of International Law' 2013, vol. 3 , no. 2

25. Sands P., 'Unilateralism', values, and international law, 'EJIL' 2000, vol. 11, no 2

26. Scovazzi T., The negotiations for a binding instrument on the conservation and sustainable use of marine biological diversity beyond national jurisdiction, 'Marine Policy' 2016

27. Simma B., From Bilateralism to Community Interest, 'RCADI' 1994

28. Tams C. J., Individual States as Guardians of Community Interests, [in:] U. Fastenrath, R. Geiger, D.-E. Khan, A. Paulus, S. von Schorlemer, C. Vedder (eds), 'From Bilateralism to Community Interest: Essays, Honour of Bruno Simma', Oxford 2011

29. Tams C. J., Enforcing obligations "erga omnes" in international law, Cambridge 2009 
30. Tladi D., The Common Heritage of Mankind and the Proposed Treaty on Biodiversity in Areas beyond National Jurisdiction: The Choice between Pragmatism and Sustainability, 'Yearbook of International Environmental Law' 2014, vol. 25

31. Tronchetti F, The Exploitation of Natural Resources of the Moon and Other Celestial Bodies, Nijhoff, 2009 